\title{
INFECTION AND CROSS-INFECTION IN A PAEDIATRIC GASTRO-ENTERITIS UNIT
}

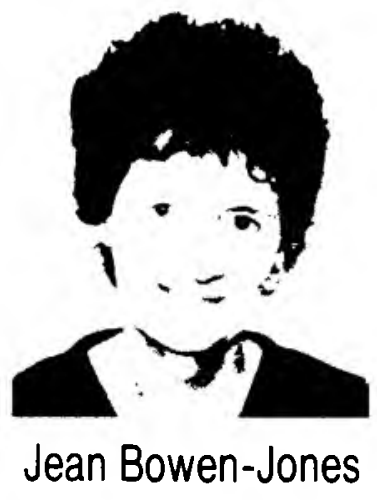

\begin{abstract}
A two month study to investigate the incidence of nosocomial infection was conducted in a paediatric gastroenteritis ward of a black academic hospital. Enteric pathogens were identified on admission in $61(47,2 \%)$ of 129 patients; 56 bacterial and 25 viral. Six per cent of patients had a combination of bacterial and viral pathogens. Enteric pathogens most frequently identified on admission were Campylobacter jejuni in 22\%. Rotavirus in $19.3 \%$. EPEC in $10.8 \%$ and Shigella spp. in 6,9\% patients. Twenty six (20\%) patients had more than l enteric pathogen. The nosocomial infection rate was recorded at $17,1 \%$. EPEC occurred most commonly in 5,3\% patients. Salmonella typhimurium in
\end{abstract}

$4,6 \%$ and Shigella spp. in $2,3 \%$. Nosocomial infections increased the mean length of hospital stay from 7,220,2 days. Contributory factors to the spread of nosocomial infection were the unsatisfactory methods of bathing patients and giving naso-gastric feeds.

\section{Opsomming}

in Studie in die insidensie van hospitaal-verworwe infeksie is oor 'n tydperk van 2 maande in die pediatriese gastro-enteritis afdeling van in swart akademiese hospitaal gedoen. Enterese patogene is by opname geidentifiseer in $61(47,2 \%)$ van die 129 pasiënte; 56 bakteriël en 25 viraal. Ses persent van die pasiënte het 'n kombinasie van bakteriële en virale patogene gehad. Enteriese patogene wat die meeste by opname voorgekom het, was Campylobacter jejuni in $22 \%$, Rotavirus in $19,3 \%$, EPEC in $10,8 \%$ en Shigella spp. in $6,9 \%$ van die pasiënte. Ses-en-twintig pasiënte (20\%) het meer as een enteriese patogeen gehad. Die hospitaalverworwe infeksie syfer was $17,1 \%$ EPEC was die algemeenste in $5,3 \%$ van pasiënte, Salmonella typhimurium in $4.6 \%$ en Shigella spp. in $2,3 \%$. Hospitaal-verworwe infeksies het die gemiddelde duur van hospitalisasie van 7,2 tot 20,2 dae verleng. Faktore wat bygedra het tot die verspreiding van hospitaal-verworwe infeksie was onbaredigende metodes vir die was van pasiënte en vir die toedien van nasogastriese voeding.

\section{INTRODUCTION}

Acute gastro-enteritis is the major cause of death in the infant population of black, coloured and Asiatic communities of South Africa, and ranks second to pneumonia in the white community.

Bulletin 60 WHO states the median incidence of diarrhoeal disease as 2,2 episodes per child per year up to the age of 5 years. Repeated attacks of enteritis severely aggravate the already poor nutritional state of black children, with consequent increased susceptibility to a variety of infectious agents, and thus increased morbidity.

A two month study was conducted on a paediatric gastro-enteritis unit of a black academic hospital.

Aims of study were to:

1. Identify bacterial and viral pathogens causing diarrhoea.
2. Document nosocomially acquired infections.

3. Investigate nursing and other practices which may predispose to infection.

\section{Definition of nosocomial infection}

A nosocomial enteric infection was considered to have occurred when a pathogen was detected for the first time in a third or subsequent stool specimen collected 48 hours or later following admission.

\section{Ward Environment}

The 52 bed paediatric gastro-enteritis ward has a turnover of approximately 150 patients per month. Seasonal variations occur with the highest number of admissions in the summer months. During busy periods the close proximity of cots and staff shortage increases the risk of cross-infection.

\section{METHODS}

Patients

Stool specimens or rectal swabs were collected for bacterial and viral examination on admission, the following day and thereafter twice weekly. (Bacteriological testing was supervised by a senior technician to maintain consistency in results) Details were recorded of the course of illness, including temperature and frequency of diarrhoea, antibiotics received and note was made of gentamycin resistance.

Blood specimens were collected for culture on admission and when clinically indicated. A social history questionnaire was recorded on admission.

\section{Staff}

Stool specimens were collected for culture from nurses and boarder mothers (breast feeding mothers who stayed at hospital to care for their babies). Hand swabs were 
collected from nurses, including milkkitchen staff, doctors, boarder mothers and domestic staff at various times throughout the day. Procedures were observed and note taken/specimens collected if desirable.

\section{Environment}

Specimens were collected from the environment to try to determine means of spread of pathogens. Specimens of feeds and feeding equipment were collected.

\section{RESULTS}

\section{Demography - Patient population}

One hundred and thirty black children, 75 male and 55 female, were admitted over the 8 week period from 25 July - 17 September 1988, suffering from severe gastro-enteritis necessitating intravenous rehydration. Their ages ranged from 2 weeks - 5 years 8 months. Seventy four per cent of patients were under 1 year of age. See Table I. They gave a history of diarrhoea and vomiting from $1-21$ days (mean of 3 days). A history of previous diarrhoeal disease was obtained in 33 $(25 \%)$ children. Enemas had been administered to $32(25 \%)$ patients; these included soap, milk, hebs, ash, alum and castor oil. In many cases it was not known whether diarrhoea had preceded or followed enema administration.

\begin{tabular}{|ccc|}
\hline \multicolumn{1}{c|}{ TABLE 1 } \\
Age of Patients & & \\
From: $2 / 52-2 / 12$ & 33 & $(26 \%)$ \\
$3-6$ months & 29 & $(22 \%)$ \\
$7-12$ months & 33 & $(26 \%)$ \\
$13-24$ months & 22 & $(17 \%)$ \\
$25-68$ months & 13 & $(9 \%)$ \\
TOTAL & 130 & $(100 \%)$ \\
& & \\
\hline
\end{tabular}

\section{Social History}

Social history revealed that piped drinking water was available to $50(39 \%)$ patients and water-borne sanitation for 17 (13\%). The chief care-giver was the mother in $73 \%$ patients, a relative in $21 \%$ and only $5 \%$ were looked after by a paid care-giver. Nutritional history obtained from 90 mothers revealed that only 12 babies were solely breast-fed up to the age of 4 months. Evidence of malnutrition was noted in $31 \%$ patients (with weights below $80 \%$ of expected weight for age on the standard percentile chart) and some presented with concomitant illnesses. See Table II.

\begin{tabular}{|lcc|}
\hline \multicolumn{3}{|c|}{ TABLE 2 } \\
Additional I/lnesses on Admission \\
Marasmus/ K washiorkor & 40 & $(31 \%)$ \\
Post measles broncho-pneumonia & 3 & $(2,3 \%)$ \\
Pneumonia & 10 & $(13 \%)$ \\
Herpes & 2 & $(1,5 \%)$ \\
? Pulmonary tuberculosis & 3 & $(2,3 \%)$ \\
Urinary tract infection & 2 & $(1,5 \%)$ \\
& & \\
\hline
\end{tabular}

Total Laboratory Findings

Enteric pathogens, bacterial or viral, were found on admission in 61 of $129(47,2 \%)$ patients. A total of 81 pathogens were recorded from these 61 patients; 56 bacterial and 25 viral. In 10 of these 61 (6\%) patients a combination of bacterial and viral pathogens were isolated. A further 8 patients without demonstrable enteric pathogens on admission subsequently acquired nosocomial pathogens, bringing the total with enteric pathogens to $69(53,4 \%)$. A total of 105 pathogens were recorded from the 69 patients by the end of the study. In 43 patients only one enteric pathogen was demonstrated, 22 patients had two pathogens, 5 patients demonstrated three pathogens, whilst 1 patient had four pathogens. See Table III.

\section{Bacteriological Findings}

Campylobacter jejuni was present in the stools of $28(22 \%)$ patients on admission; 18 of these had at least one other enteric pathogen. Only 2 patients nosocomially acquired Campylobacter jejuni, and that occurred 7 days after admission.

Campylobacter jejuni was observed to be shed in the stool for up to 32 days.

Enteropathogenic serotypes of $E$. coli $(E P E C)$ were found in $14(10,8 \%)$ patients on admission; another 8 patients nosocomially acquired $E P E C$ during the duration of their illness; only $4 E P E C$ were not associated with other pathogens. Two patients demonstrated 2 different EPEC serotypes. $E P E C$ was nosocomially acquired between 5 and 43 days following admission.

Shigella flexneri was isolated from the stools of 6 patients on admission and was acquired nosocomially in one. Shigella sonnei was present on admission in 3 patients and acquired nosocomially in two. The nosocomial infections occurred between 5 and 9 days following admission.

Salmonella reading, seftenberg and typhimurium were each demonstrated in one patient respectively on admission. A further 6 acquired a nosocomial Salmonella typhimurium between 6 and 18 days following admission. In one patient it was shed in the stool for 15 days.

Cryptosporidium was present on admission in 2 patients and Aeromonas hydrophilia was demonstrated in one, and acquired nosocomially in another.

\section{Viral Findings}

Rotavirus was isolated from the stools of 25 of 129 patients (19\%) on admission (21 of these were under 6 months of age), and acquired nosocomially by a further 3 patients between 9 and 11 days following admission. It was shed for up to 10 days. Bacterial pathogens were associated with 10 of the 28 patients with Rotavirus.

\section{Nosocomial Enteric Pathogens}

Nosocomially acquired enteric pathogens occurred in $22(17,1 \%)$ patients. Of these, $14,8 \%$ were bacterial and $2,3 \%$ viral. See Table III. The time of acquisition ranged from 3-43 days (mean of 12,5). Eight of these patients did not have enteric pathogens demonstrated on admission, whereas the other 14 acquired additional nosocomial pathogens. The length of stay in hospital ranged from 2-48 days (mean 7,2 ) but for those with a nosocomially acquired enteric infection the mean increased to 20,2 days. Other non-enteric nosocomial infections which occurred in the study were 1 pneumonia, 1 bronchitis and 1 abscess on the scalp.

\section{Deaths due to gastro-enteritis}

During the study period $5(3,8 \%)$ patients died. Three patients were under one year of age. None of the deaths was due to nosocomial infection.

\section{Antibiotics and Gentamicin Resistance} received antibiotics. These included Bactrim, Neomycin, Amoxil, Penicillin, Ampicillin, Flucloxacillin, Chloramphenicol, Erythromycin, Amikacin and Vancomycin. Gentamicin resistant bacteria were recovered from the stools of $110(85 \%)$ patients. In $8(6 \%)$ patients gentamicin resistance was noted in the first specimen collected on the day of admission. It is not known whether they had been previously hospitalised or received antibiotics. In $84(77 \%)$ patients gentamicin resistance occurred within 1-4 days ( 1 st and 2 nd specimen). Of the 19 One hundred of $129(77,5 \%)$ patients
TABLE 3

Enteric Pathogens Isolated from Stool Specimens of 129 Patients

\section{Bacteria}

Campylobacter jejun

E. coli (EPEC)

Crypiosporidium

Shigella sonnei

Salmonella syphimurium

Salmonella sefienberg

Salmonella blockley

Salmonella reading

Virus

Rotavirus

Total of bacteria and virus
Shigella Jexneri lsolated from Ist or 2nd specimen

$28 \quad(22 \%)$

$14 \quad(10,8 \%)$

$\begin{array}{ll}2 & (1,5 \%) \\ 6 & (4,6 \%)\end{array}$

$3 \quad(4,6 \%)$

I $\quad(0,7 \%)$

I $\quad(0.7 \%)$

l $\quad(0,7 \%)$

On Admission

$25 \quad(19,3 \%)$

82
-
Nosocomially

$\begin{array}{lll}2 & & (1,5 \%) \\ 8 & & (6,2 \%) \\ \overline{1} & & (0,7 \%) \\ 2 & & (1,5 \%) \\ 1 & (0,7 \%) \\ 6 & (4,6 \%) \\ - & & \\ - & & \\ 3 & (2,3 \%) & \\ 22 & (17 \%) & \end{array}$

Total $(23,2 \%)$
$(16,2 \%)$

$(1,5 \%)$

$(5,4 \%)$

$(3,8 \%)$

$(1,5 \%)$

$(5,4 \%)$

$(0,7 \%)$

$(0,7 \%)$

$(0,7 \%)$

$(21,7 \%)$
Aeromonas hydrophilia

$1 \quad(0 ; 7 \%)$ 
(15\%) patients who did not acquire gentamicin resistant organisms $10(53 \%)$ received no antibiotics.

Blood Culture and Stool Specimens

Sixteen $(12,3 \%)$ patients had positive blood cultures on admission. Three patients had the same bacteria isolated from blood culture and stool specimen.

\section{Results from Unit Personnel}

Hand swabs are randomly collected (when their hands were supposedly clean) from various members of staff and boarder mothers at various times throughout the day. Only two positive cultures were obtained; one from a milk kitchen nurse and the other from a ward nurse. Both the
Klebsiella spp. and Acinetobacter spp. were resistant to Gentamicin and Amikacin. One pathogenic organism, Yersinia Enterolytica was identified in the stool of a boarder mother who was asymptomatic.

\section{Results from the Environment}

Table IV demonstrates the presence of pathogens in cleaning equipment, i.e. floor polisher, broom, mops and dusters; some of them Gentamicin resistant. Sinks used for bathing patients, and the towel/mattress on which the children were laid to dry after bathing, demonstrated growth of enteric pathogens (many of them Gentamicin resistant), and Staphylococcus aureus (S. Aureus).

\begin{tabular}{|c|c|c|c|}
\hline \multicolumn{4}{|c|}{$\begin{array}{c}\text { TABLE 4 } \\
\text { Pathogens Cultured from Environment }\end{array}$} \\
\hline Specimens & Number & No growth & Pathogens \\
\hline Agar plates & 9 & 2 & $\begin{array}{l}3 \text { Acinetobacter spp. } \\
72 \text { Klebsiella spp. } \\
2 \text { S. aureus }\end{array}$ \\
\hline Cot mattresses (empty cots) & 7 & 7 & No growth \\
\hline Cot mattresses (occupied) & 3 & $\mathbf{0}$ & $\begin{array}{ll}\text { Enterobacter spp. } & \text { Gentamicin and } \\
\text { Acinetobacter } & \text { Amikacin resistant }\end{array}$ \\
\hline Bedclothes (clean) & 10 & 10 & No growth \\
\hline Bedclothes (occupied) & 3 & 0 & 3S. aureus (Cloxacillin resistant) \\
\hline $\begin{array}{l}\text { Bath mattress (towel and } \\
\text { blanket) }\end{array}$ & 12 & 4 & $\begin{array}{l}3 \text { S. aureus (Cloxacillin resistant) } \\
8 \text { Klebsiella spp. (2 Gentamicin resistant) } \\
1 \text { Enterobacter spp. } \\
1 \text { Acinetobacter spp. }\end{array}$ \\
\hline Sinks used for bathing & 7 & 4 & $\begin{array}{l}2 \text { Klebsiella spp. (Gentamicin resistant) } \\
2 \text { Acinetobacter (1 Gentamicin resistant) } \\
1 \text { Pseudomonas spp. (Gentamicin resistant) } \\
1 \text { E. coli (Gentamicin resistant) }\end{array}$ \\
\hline Taps (sink) & 2 & 2 & No growth \\
\hline Flannels & 3 & 3 & No growth \\
\hline Soap & 3 & 3 & No growth \\
\hline Scales & 4 & 4 & No growth \\
\hline Vaseline & 4 & 4 & No growth \\
\hline Thermometers & 8 & 8 & No growth \\
\hline $\begin{array}{l}\text { Cockroach } \\
\text { Floor polisher }\end{array}$ & 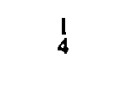 & $\begin{array}{l}1 \\
3\end{array}$ & $\begin{array}{l}\text { No growth } \\
\text { Klebsiella spp. (Gentamicin resistant) } \\
\text { Enterobacter spp. }\end{array}$ \\
\hline Broom & 1 & 0 & I S. aureus (Cloxacillin resistant) \\
\hline Mop & 2 & 1 & I Enterobacter spp. (Gentamicin resistant) \\
\hline Dusters & 3 & $\mathbf{0}$ & $\begin{array}{l}3 \text { Enterobacter spp. (I Gentamicin resistant) } \\
1 \text { E. coli }\end{array}$ \\
\hline
\end{tabular}

\begin{tabular}{|c|c|c|c|}
\hline \multicolumn{4}{|c|}{ TABLE 5} \\
\hline \multicolumn{4}{|c|}{ Feeds and Feed Equipment } \\
\hline Specimens & Number & Growth & Puthogens \\
\hline Milk feeds & 32 & 14 & $\begin{array}{l}18 \text { - Streptococci, Klebsiella spp., } \\
\text { Acinetobacter, E. coli, Enterobacter spp. } \\
10^{4}-10^{5}\end{array}$ \\
\hline \multicolumn{4}{|l|}{ Feed equipment: } \\
\hline $\begin{array}{l}\text { Bucket } \\
\text { Jug }\end{array}$ & $\begin{array}{l}4 \\
2\end{array}$ & 3 & 1-Acinetobacter spp. and Streptococci \\
\hline \multicolumn{4}{|c|}{$\begin{array}{l}\text { Equipment for naso-gastric } \\
\text { feeds: }\end{array}$} \\
\hline Feed tube (barrel) & 10 & & $\begin{array}{l}\text { 6- Klebsiella spp., Enterobacter spp., } \\
\text { Acinetobacter spp., Pseudomonas spp., } \\
\text { Enterococcus faecium 104-105 }\end{array}$ \\
\hline \multicolumn{4}{|l|}{ Connections: } \\
\hline Naso-gastric tubes & 20 & 8 & $\begin{array}{l}12 \text { - Enterobacter spp., E. coli, Klebsiella } \\
\text { spp., Acinerobacter spp., (50\% Gentamicin } \\
\text { and amikacin resistant) }\end{array}$ \\
\hline Feeding bottle teats & 4 & $\mathrm{I}$ & 3-Acinetobacter spp. \\
\hline Ordinary ward food & 3 & 1 & $2-$ Klebsiella spp., E.coli and Acinetobacier \\
\hline
\end{tabular}

Feeds and Feed Equipment

It may be seen in Table $V$ that many milk feeds contained bacteria $10^{4}-10^{5}$. Ordinary ward food from the kitchen for recuperating children also contained enteric pathogens. Equipment for nasogastric feeds (barrels of syringes and plastic connections to connect the tubing to the patients' naso-gastric tube) were colonised with bacteria. The naso-gastric tubes in situ rapidly become colonised with the patients' enteric flora ( $50 \%$ of them were Gentamicin and Amikacin resistant).

\section{DISCUSSION}

Enteric pathogens were isolated on admission from the stools of $47,2 \%$ patients with diarrhoea. The isolation rate is similar to findings in other studies in South Africa, Central African Republic ${ }^{1+3}$ and other developing countries in the world. 5,6

Campylobacter jejuni was the most frequently encountered bacteria in this study occurring in $22 \%$ patients. Other studies demonstrate Campylobacter spp. less commonly; 10,9\% Georges et al., ${ }^{3} 3,5 \%$ Loening, 10,2\% Lloyd Evans et al. EPEC occurred in $10,8 \%$ patients in this study; in Georges et al. 12,1\%1 and Koornhof $33,3 \%,{ }^{2}$ Shigella spp. ocurred in $6,9 \%$ and Salmonella spp. in 2,8 patients. Rotavirus occurred in $19,3 \%$ patients (of which $84 \%$ were six months or younger which is confirmed in other studies). ${ }^{1,4-6}$ Georges et al. ${ }^{\prime}$ demonstrated the incidence of $17,6 \%$, Schoub et al. at $19 \% \%^{4}$ and Loening at $15,4 \%$. The reported incidence is said to peak in winter months. ${ }^{8}$ Six per cent of patients in this study had viral and bacterial pathogens, whereas Schoub et al. ${ }^{1}$ demonstrated the incidence in his study at $23 \%$. Other studies have demonstrated the presence of more than one enteric pathogen in stool specimens. ${ }^{1,2,4,7}$

The study conducted over 8 weeks during a non-busy period demonstrates a nosocomial enteric infection rate of $17,1 \%$ with increased morbidity, and prolonged hospitalisation. In a busier period with a higher bed occupancy rate the risk of nosocomial infection would probably increase.

The high incidence of malnutrition, concomitant illness, age of patients and selective effect of antibiotic therapy probably contributed to the increased risk of nosocomial infection in the compromised host. The pathogen most frequently isolated as an agent of nosocomial infection was $E P E C$ which occurred in 6,2\% patients. Dupont et al. ${ }^{9}$ state $E P E C$ as third to Clostridium difficle and Salmonella as a reported cause of nosocomial infection in NNIS data.

The mode of spread may be from the hands of unit personnel or fomites. Pharyngeal colonisation of infants occurs and may be an intermediate step in the spread of infection. The organism may also be detected in dust and fomites in the ward environment. Salmonella typhimurium occurred as a nosocomial infection in $4.6 \%$ patients. This is confirmed as a frequent agent in other studies ${ }^{8,9}$ and is typically 
spread by hands, fomites or in dust.

A WHO consultant wrote that such infections could be airborne and evidence suggests that vacuum cleaners could disseminate Salmonella typhimurium. ${ }^{10}$ Shigella spp. which occurred as a nosocomial infection in 3 patients was high, as the initial patients admitted with Shigella spp. amounted to only 9 , indicating a high potential for spreading. Other studies ${ }^{8,9}$ indicate the cross infection rate as low, but the high incidence in this study may be due to the very low dose of organisms (less than $10^{3}$ ) necessary to produce disease. Rotavirus occurred as a nosocomial infection in $2,3 \%$ patients, which is a low rate considering there were 25 initial patients and the virus was shown to be shed for up to 10 days. Campylobacter jejuni likewise occurred rarely as a nosocomial agent in 2 patients, although 28 had Campylobacter isolated on admission, and the organism was evidenced to be shed in the stool for up to 32 days. This indicates the low incidence of horizontal spread.

It may be seen from results of hand swab cultures that hand disinfection by staff with Chlorhexidine $0,5 \%$ and alcohol $70 \%$ handspray was strictly observed between patient contact. Even domestic staff were observed to be fastidious in this matter. It would therefore appear that hands of unit personnel were not important factors in the spread of cross infection.

Two main areas of weakness were observed in the nursing procedures which were probable factors in the spread of cross infection a) the bath routine and b) the method of naso-gastric feeding. During the daily bath routine babies and young children werebathed in succession in the ward sinks which were not adequately disinfected between each bathing (see Table IV). After being bathed patients were laid on a shared blanket covered with a towel.

As the towel became wet, pathogens ere able to be transferred to the blanket below, and could subsequently be transferred to the next patient to be dried. Enteric pathogems resistant to Gentamicin were isolated from both sinks used for bathing and from the bath mattress (towel and blanket) on which patients were dried.

Another important contributory factor to the spread of nosocomial pathogens was the method of giving naso-gastric feeds, and the feeds themselves, of which $56 \%$ contained bacteria $10^{4}-10^{5}$. See Table V. Babies who were unable to take feeds orally were fed via a naso-gastric tube. The naso-gastric tube became colonised, within 24 to 48 hours of insertion, with the patients' enteric flora ( $50 \%$ of which were resistant to Gentamicin and Amikacin). The means of giving the naso-gastric feed was via the barrel of a $20 \mathrm{ml}$ syringe connected to a rubber tube with a plastic connection to attach it to the patients' naso-gastric tube. A common syringe barrel, tubing and connection was used consecutively for each patient without any attempt to sterilise it between patients. It was rinsed through with cold water only. Seventy two per cent of cultures from feed equipment proved contaminated with enteric pathogens.

It would appear therefore, that patients receiving 3 hourly naso-gastric feeds were exposed to high risks of acquiring a nosocomial infection from contaminated feed equipment. The close proximity of cots and the constantly high bed occupancy rate in the acute admission ward made nursing procedures difficult to perform without contamination of nurses' hands or equipment. Although nurses were observed to wash/disinfect hands before performing a "procedure" casual contact by touching bedlinen or a patient could result in pathogens being spread (See Table IV). It must be remembered that the colonised patient is a silent source of bacteria.

It is possible that the nosocomial infection rate was higher than reported, and the acquisition of the cross infection could have occurred within 48 hours of admission whilst in the acute admission ward. If pathogens found in a second stool specimen within 48 hours of admission

(following a previous negative specimen) are considered to be nosocomial the incidence of cross infection increases to involve $34(26,3 \%)$ patients.

\section{BIBLIOGRAPHY}

1. Georges, M.C., et al. Parasitic bacterial and viral enteric pathogens associated with diarrhoea in the Central African Republic. $J$ Clinical Microbiology. May 1984, 57I-575.

2. Koornhof, H.J., Robins-Browne, R.M. Richardson, N.J., Cassel R. Etiology of infantile enteritis in South Africa. Israel $J$ Med Sc 15: 341-347, 1979.

3. Brandt, C.D., et al. Paediatric viral gastroenteritis. J Clinical Microbiology. 25 March 1983.

4. Schoub. B.D., Greef, A.S., Lecatsas, G. Gastro-enteritis in black African infants. National Institute for Virology.

5. Rodriquez, W.J. Rotavirus: A cause of nosocomial infection in a nursery. $J$ Paediatrics 101: 274-277, 1982.

6. Schoub, B.D., et al. Virus particles and gastro-enteritis in black and white children in Rhodesia. Soush African Medical Journal $(S A M J) 49,859,17$ May 1980.

7. Spencer, I.W.F., Coster, M.E.E. The epidemic of gastro-enteritis in infancy. SAMJ 43, 1391, 1438, 1446.

8. Hughes, J.M., Jarvis, W.R. Nosocomial gastro-intestinal infections. Prevention and control of nosocomial infections. Ch 24 Wenzel.

9. DuPont, H.L., Ribner, B.S. Infectious gastro-enteritis. Ch 32 Hospital Infections. Brachmann and Bennett.

10. Haddock, R.L. Salmonella in vacuum cleaners. Lancet I3 September 1986.

\section{Acknowledgements}

I would like to thank Dr D.F. Wittenberg, Dept. of Paediatrics for allowing me to do the research and Dept. of Microbiology, King Edward VIII Hospital, Durban.

Jean Bowen-Jones

R.N., COMM.NURS., ORT.NURS. Department of Nursing. University of Natal 